\author{
原 著 論 文 \\ 平木田ガス田に拈ける層位トラップについて \\ 加 藤 正 和*.片 平 忠 実* \\ (昭和 42 年12月20日受理)
}

\title{
Stratigraphic Traps in Hirakida Gas Field
}

by

Masakazu Kato and Tadami Katahira

\begin{abstract}
Kita-Kambara Plain has recently become one of the most active exploration and development area in Japan. Hirakida gas feld is situated near the east boundary of this Plain. Narrow shelf area may be extending along the northwestern flank of the Kushigata Mountain range. Sedimentation and truncation along the hinge line has large influence on gas accumulation of this field. Detailed structural and stratigraphic analysis may be necessary to determine the most potential trend of this type of trap.
\end{abstract}

\section{1.はしがき}

北溥原平野は，新鼬平野上ともにわが国て最名活代つ な探鈸拉よび開発活動が行なわれている地域でる。平 木田ガス田はこの平野の東縁部で発見された（第 1 図)。 このガス田のガスは主として層位トラップに集樻したも

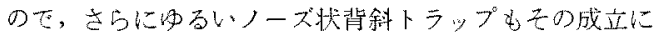
関与していると考之られる。屡位卜ラップの形成には， 不整合による切頭作用，拈よびヒンジラインにおけるた い積作用が大きな関連を子っている。曆位トラップは， ヒンジラインから盈地方向に向加って存在すると考六ら 机る。ヒンシラインに执いては，砂は陸棚部に批けるよ り急激に尖隇する。

このような性貿のガス層の発見は，わが国では非常に 珍らしいものである。しかし平野部に淤けるノルマな背 斜構造の探鉱が，かなり困難に直面している現状から， 層位トラッブあるいは層位トラップを主体とする組两合 わせの探鎕か，今後は一そう重要視さ礼るようになるて あろう。こういう型のトラップは，北蒲原平野の東緑部 だけでなく，新津油带の西方平野部などの地域にも期待

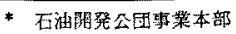

することができる。

第 1 图平不田ガス回位置図

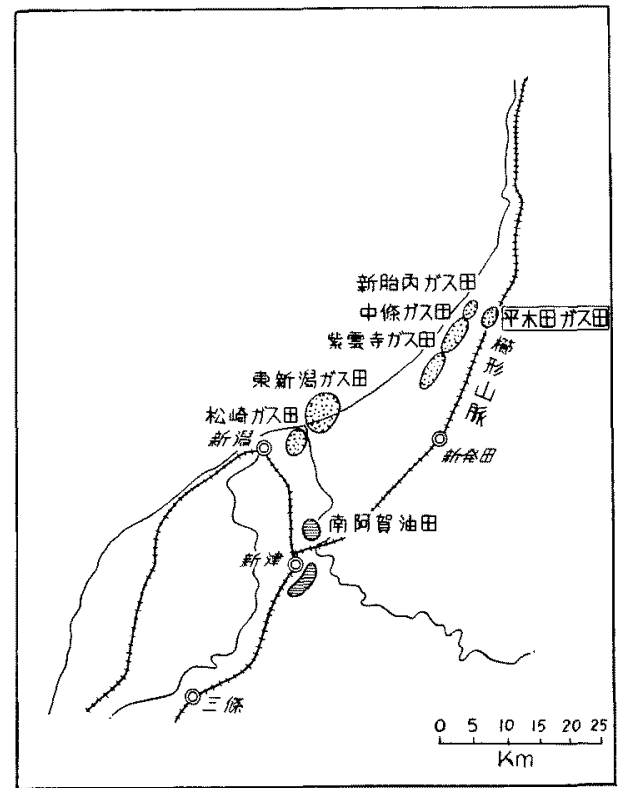


平木田ガス田地域ては，現在ままてに10本の境斗が掘 さくされ，守てに津川層ないしての下位層（アルコーズ サンドをよびグラニットウォッシュより成る)孛で探 鉱が行なわれているが，これらの下值層の中にはまだカ スの賦存は確認されていない。この地域のガス層は寺泊 層・䊒公㞗(拉よじ西山層)中に分布する。本文は既存の 坑井データより,これらの地層中に晾るガスの分布地 域劣予測すること老目的とする。

\section{2. 層位トラップの形成}

平水田地域加，飞の北方約 $2 \mathrm{~km}$ の眚駄天山地域に わたって，七谷層は全般的にその層厚に大した変化がな く，しか子縁辺部の同層としては比较的㕌い（厚さ約 $700 \sim 750 \mathrm{~m}$ ) のが特徴てある（岩相的な変化は瑟力られ るけれども)。同層沈皘待には，この地域はかなり安定

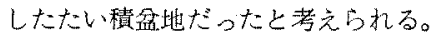

本地域で，厥地的な隆起運動加本格的に開始されたの は寺泊期であって，ての未期の不整合現象に見られるよ うに, 隆起部の寺泊層の一部はかなりの削はくをうけて いる。寺泊層は，電検・カッティング拈よび有孔虫化石
対比によってつ3のゾーンに区分される。すなわち， $\mathrm{a}$ 泥岩層， $\mathrm{b}$ 砂岩層执よび $\mathrm{c}$ 泥岩層である。b 砂岩層の 中に主要レザーパーが含有さ机る。第2図の対比図に

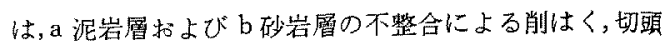
の状況支模式的に示す。この不整合は, コンティニュア スディップメーター(CDM)の電子計算機に上る高密度 解析結果加も，その存在を虫は推定することがでる。 とくに SK 3, SK 4 牤よび SK 6 のような, 符造上あが っている坑井のディップパターンには，不整合面の下 位に特徽的な風化带のパターンも認められ，その上下て 構造差があることは明らかである(第3図)。

これに対して，SK 2 のような傾斜下方の坑井に括い ては，不整合面の上下て多少の構造差はあるとしても， 前記のような風化帯のパターンは不明りょうである(第 4 図)。

第 5 図は寺泊層基底による地下構造図である。これは

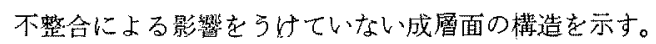
この時期に㭁いて，すでに現在の平梱および韋塥天 山棈造の肧芽形態力゙形成されている。第5图て，大体 $-1,000 \sim 1,100 \mathrm{~m}$ のコンターから地尿傾斜がやや急に

第2図平柚田力゙ ス田対比図

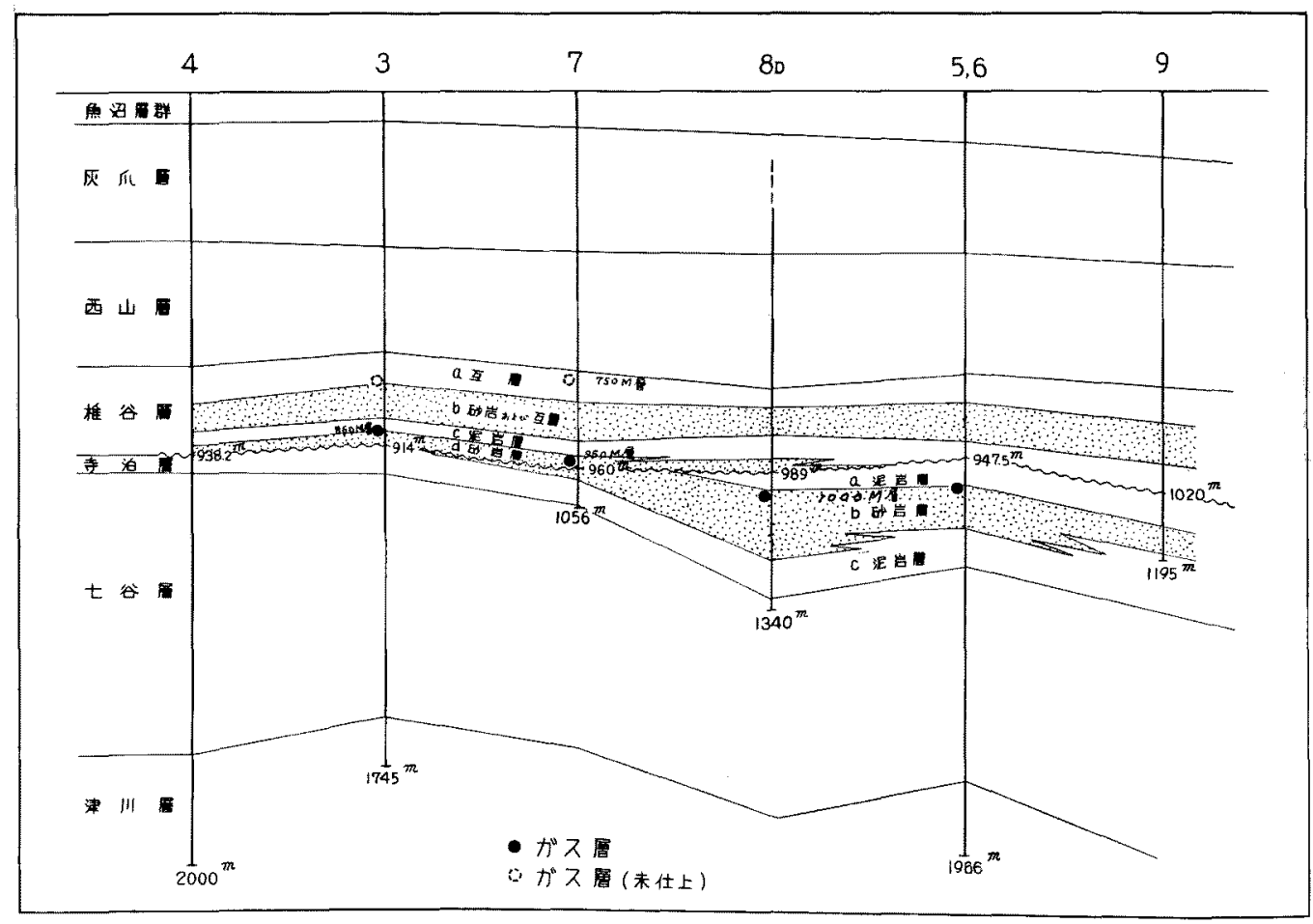

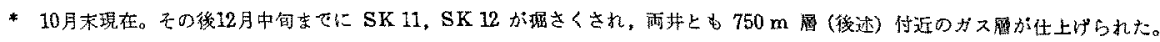




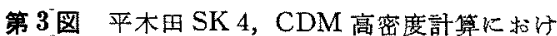
る風化带を伴な5不整合ハターン

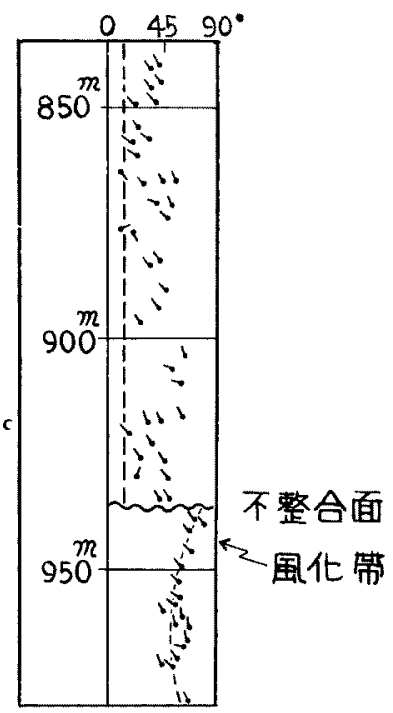

第 4 図平木田 SK 2,CDM 高密度計算に乱 る不整合ハターン

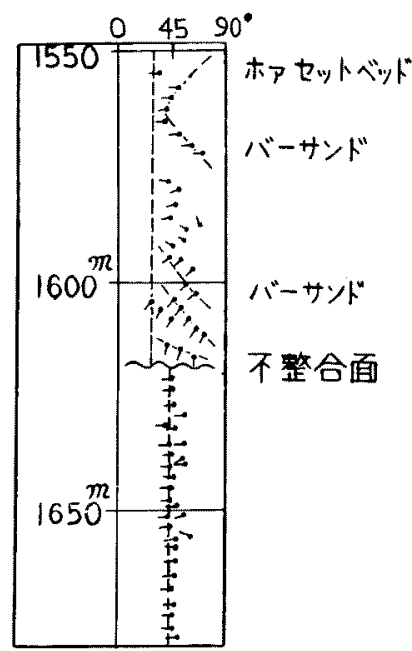

なることが垫められる。このソ゚ーンての地層倾斜は40〜 $50^{\circ}$ でありこのラインより東方忙安定陸明，また西方 は沈降鼻地をすり。この屈曲部 (flexure) が，北蒲原平 野東縁部におけるいわゆるヒンジラインたと推定され る。

寺泊層の等層原線図（第6図）によると，本層の層厚 は酉方八漱次暻くなるが，その状況は，当時の平木田满 造の形態にはあ支配されていないこと，和よびとン シラインに执いてす，とくにたい積レートの增加に伴な
第 5 図 寺泊層基底による地下㮖造図

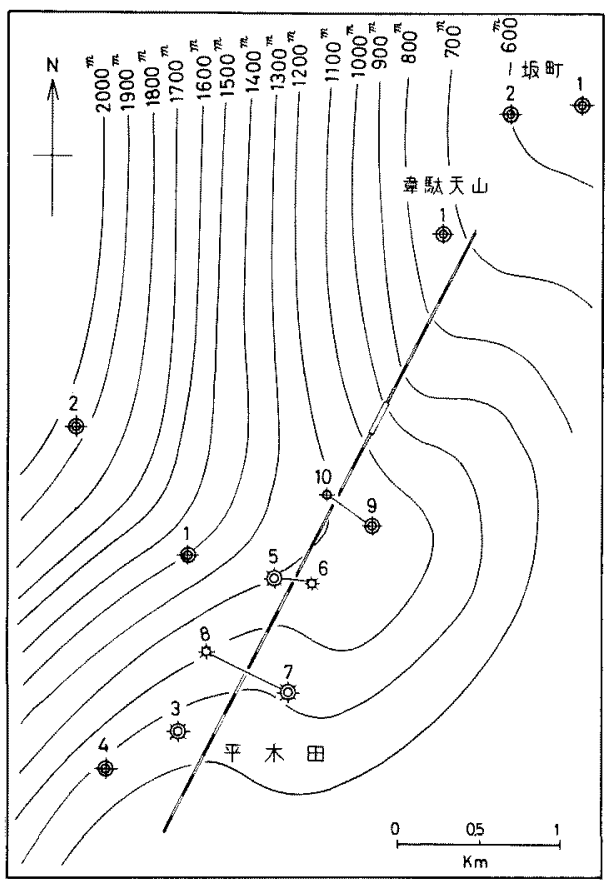

第 6 図寺泊恣等層厚線図

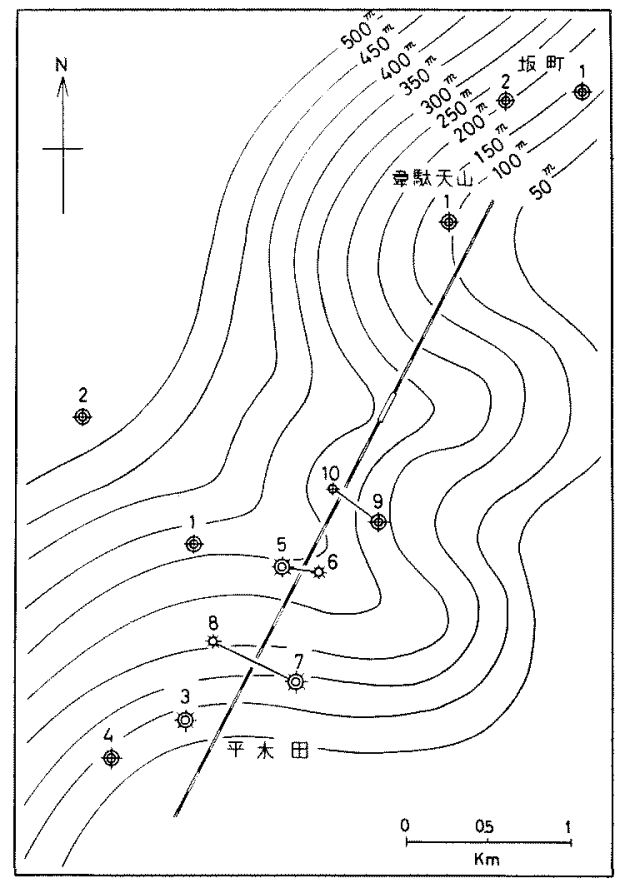


う地缯の急激な厚化は起っていないことが判る。

平末田ガス田で最分布が広い $1,000 \mathrm{~m}$ 層上よばれて いるガ層は，ヒンジシインとその付近にのみ限定され るが，1967年10月までに3坑が仕上げられている(SK

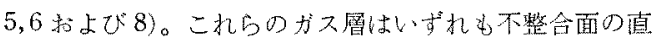
下に分分して扣り，不漫唀性のンールと傾動ないし小規 模なノーズ椣造の存在が，トラップ形成の必要杀件とな る。

寺泊層中のカ不探鉣するためには, 同尿をいくつか の㧘元にはっきりと細分寸ること，不整合面と各単元と

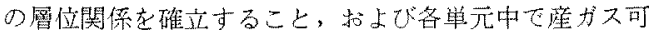
能性のあるトレンドを棈造的心摘出するこ上が必要であ 3 。

椎谷層基底の不整合面上には，西方からの海准によ。

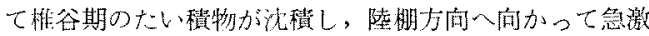
に薄化する。椎谷層のたい䆊に最も影繁しているのは， 不整合面の形熊とヒンジインに批る地層の属曲状態 こある。

椎谷層中の砂は, 主として (長) 㳂岸流によるバーサ ンドですろう。CDM の高密度計算結果に拈いて，小 規模なからら数多くの沿岸性と考えられるバーサンドパ ターンや，デルタたい䅼物に特徽的なホアセットベッ

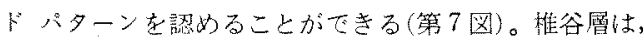
$\mathrm{a}$ 泥岩胴b互層, $\mathrm{b}$ 砂岩扣よび互層, $\mathrm{c}$ 泥岩層扣よび $\mathrm{d}$ 砂岩層に組分される。各単元は不整合部に近らくに良っ

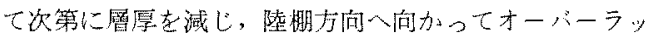
プする。

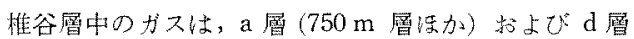
$(860 \mathrm{~m}$ 層, $950 \mathrm{~m}$ 層)に含有さ扎る。こ狄らの尿はそれ ぞれセバレートしたレザーハーであり，傾斜下方部ては すくに水層になっていて, カスが含有されているのは傾 斜上力のごく狭い籍用に限定される。平术田地域たは，

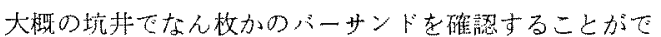

第 7 图 SK 3,CDM 高密度計算に的けるペー

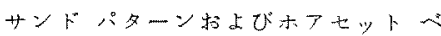

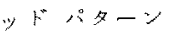
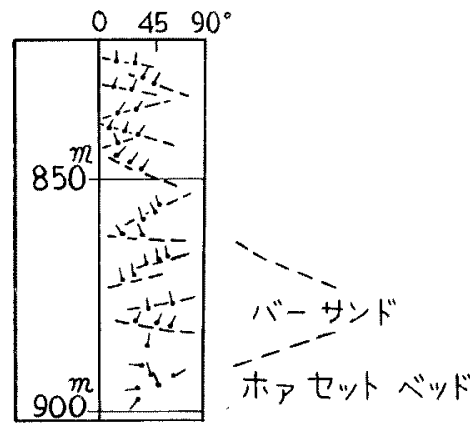

第 8 図椎谷層基底（不整合面）地下權造図

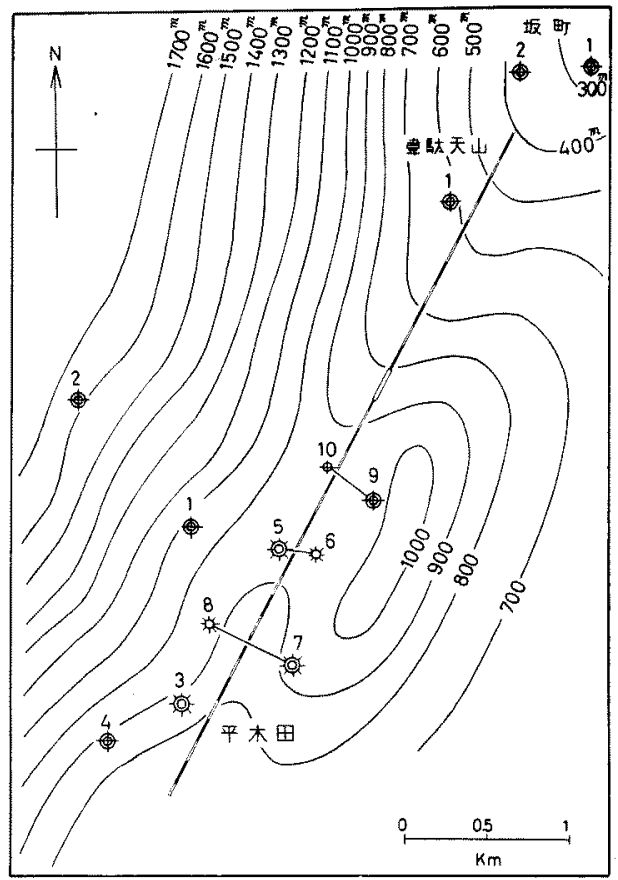

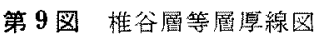

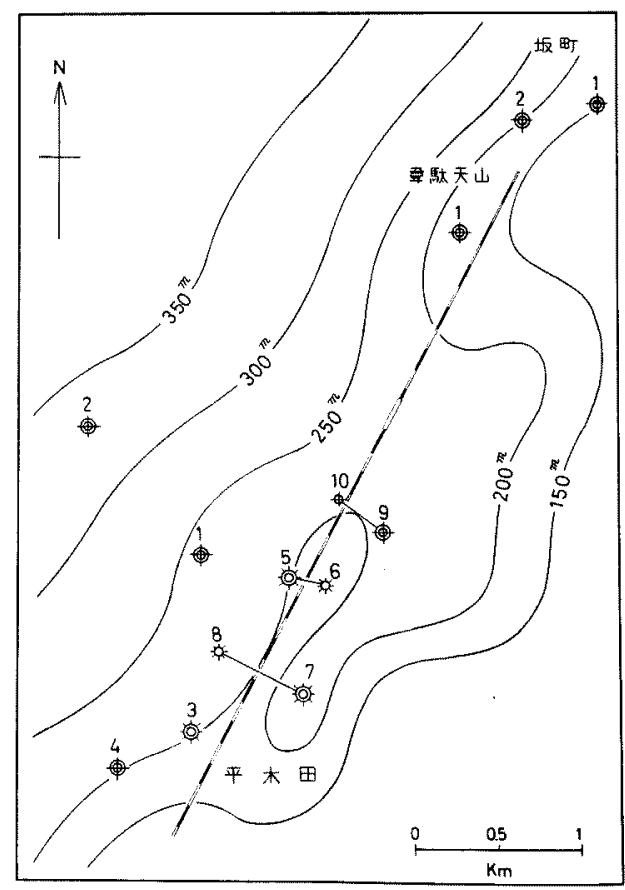




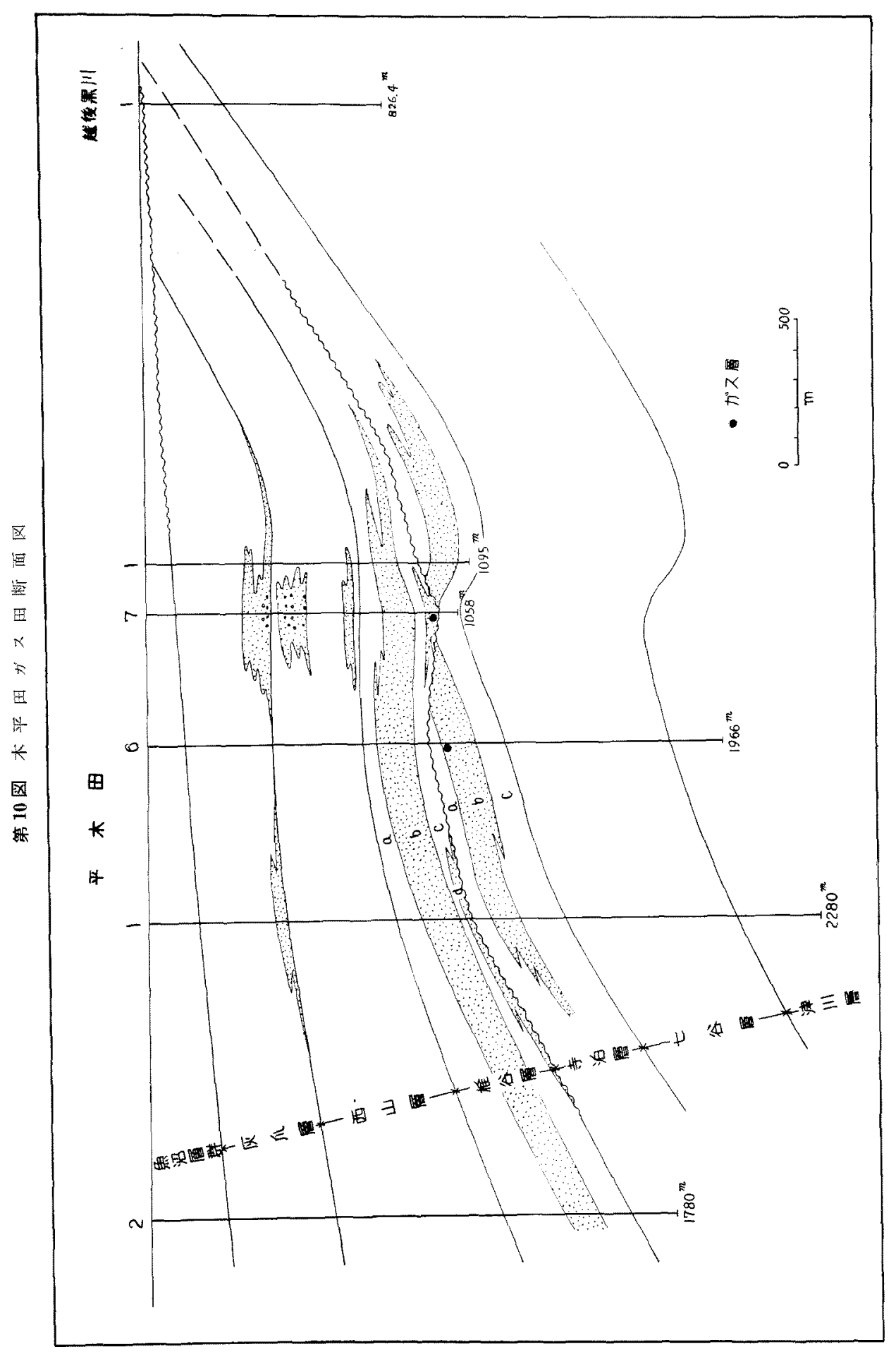


きる。しかし各砂のカスー水界面はかなり不規則なよう であり，今徬は一そう詳細な榄造图・断面図の作成等に よって，その状況をはっきりと解期して行かなければな bない。

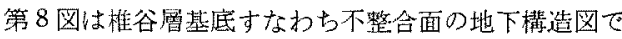

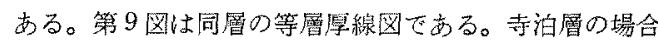

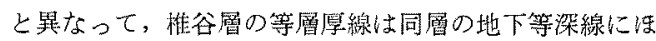
ぼ平行をあることが判る。したがって，バーサンドば海

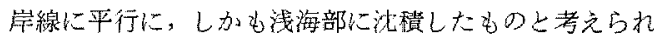
る。こ5い5砂は，等層厚線に平行な方向に，側方へ卜 レースすることができる。隆起部では惟谷層の影さは

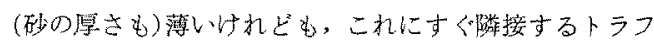
部分一例えば SK 7 号井地域のような小規模なトラフに 佶いても，砂は局地的にかなり厚々沈䅡している。

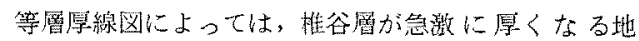
域一すなわち、この時期のヒンジラインをばっきりと摘 出することは困難でする。現在のところ, 柈谷曾中のガ スの探鈆拓よび開発を行ならためには，亦ず砂層の尖隇 部を摘出するために精密な断面図を作成すること，力 ス一水界面索估っきり決める目的で地下構造图志作成す ること，执よび厚い砂のたい䠝が期待てきるような当時 の地形的低地を等層愿線图から見出すことが必要であ る。

平本田ガス田のガス箅は，い寸゙れもメタンを主成分と するトライカスを含有し，各井と現在またのところ水 は倦とんどついていない。しかしガスの分布筑囲は比較
的狭いようであって，とくに寺泊層中の $1,000 \mathrm{~m}$ 層は力 スの産出に伴なう区力の降下が著しい。1,000 m 層は貯 溜岩としては全体としてかなりの厚さをむっているにか 加らず，全般的な連続性に艺しく，浸透率か低いと考 えられる。今後は平木由からその北方量散天山地域にわ たり，ヒンジラインおよびトラフ部に就いて，詳細な地 質学的コントロールを行ないながら，最も有效な探鈆扣 よび閶発計画を立てて行かなければなららな。

\section{3.むすび}

（1）平木由ガス由のカ゚スは, 尖堿トラップ・不整合 トラップ怙よびノーズ状背斜トラップの組み合わせによ って䝿積されたものである。

(2)このような型のトラップの探鉱杜よび開発を行

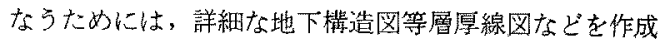
$し て$ ，造構造的要素やたい積環境的要素の識別を行な い,これに基づいて有効な掘さく計画を立てなければな bない。

謝辞；本文に紹介された資料の公表を許可された石油 開発公団事業本部，とくに本文の校閲をわずらわした同 本部鈴朴生産部長・池辺探鎕部長に深く謝意を表します。 さらに, 有孔虫化石層序について数々の責重な示唆をい ただいた同本部技術研究所新保主任、地啠学的解釉につ いてご教示をうけた探鉱部山田主任および添付された図 表・图面の作成にあたられた生産部開発課相馬昭氏に感 鹤します。 